12. N.G. Malich, L.M. Vasilev, O.A. Usov Issledovanie vliyaniya parametrov nagruzheniya na raspredelenie napryazhenij, dejstvuyushih pri razrushenii shihtovyh materialov v drobilkah // Metallurg. i gor-norudn. prom-st.-2015.-№7.-S.99-106.

https://doi.org/10.31713/m1029

\title{
RESEARCH OF THE POSSIBILITIES OF USING URBAN GREEN SPACES IN DONBASS CITIES TO RECREATE THE RESOURCE STATE OF THE MINING REGION
}

\author{
V. Sokolenko \\ Volodymyr Dahl East Ukrainian National University, Candidate \\ of technical science, Associate Professor, Ukraine \\ M. Filatiev \\ Volodymyr Dahl East Ukrainian National University, \\ Doctor of Engineering Sciences, Associate Professor, Ukraine

\section{K. Sokolenko} \\ Volodymyr Dahl East Ukrainian National University, \\ Postgraduate student, Ukraine

\section{S. Piddubnyi} \\ Volodymyr Dahl East Ukrainian National University, \\ Senior Lecturer, Ukraine
}

\section{Annotation}

Ukrainian Donbass has crossed the peak of extensive growth. Today this industrialized urbanized region has faced with a complex of problems. Sustainable urban development cannot be based only on the exploitation of natural raw materials. The task is to build a balanced model for the development of an industrial region, when the criteria for success are the quality of the environment, urban development, human potential. The exploitation of the resource base must be compensated for by the preservation of the environment. The natural landscapes of Donbass have been partially destroyed, partially changed by economic and industrial activities. There is a need to reproduce adapted green landscapes of cities in order to improve the ecological situation and restore the landscape and recreational potential of the territories. Alchevsk is in many ways the median city of Donbass. The subject of the study has chosen the green spaces of the city of general use, limited and special purpose for a period of more than 25 years, that is, the duration of the General Plan. The goal of research is to determine the species composition of green spaces typical for the cities of the Luhansk region and the establishment of a group of plants that are maximally adapted to independent growth in the urban landscape. The geographical, climatic and orographic characteristics of the city are considered, 
the analysis of the quantitative and qualitative state of the city's green spaces is carried out. The sample also covers areas of disturbed territories of waste heaps, industrial zones, landfills. Analyzed the retrospective and prospective urban planning policy in the development of green spaces, and the overall results. The actual species composition of trees and shrubs growing in the city areas has been determined. There are 44 species of trees and 20 species of shrubs registered in the city. It is desirable to spread the species composition of trees and shrubs that are used for landscaping at the expense of species that feel good in the city.

The results of the study can be taken into account in the development of measures for the greening of urban areas and the restoration of ecologically disturbed urban areas of industrial cities of the Luhansk region.

\section{Introduction}

Ukrainian Donbass is an industrial region formed on the basis of the development of the mining and metallurgical complex. A set of conditions and factors contributed to the rapid development of the region, primarily through the exploitation of natural resources. At the initial stage, these were raw material deposits, primarily coal. The metallurgical industry needs a wide range of materials and raw materials - mainly mineral. The industry produces huge volumes of industrial waste and environmentally harmful emissions. According to historical standards, a region instantly emerged, in size and population, on an industrial scale larger than individual European states [1]. But we can note the imbalance in the growth of the region, the colonial type of use of its raw materials, which led to a complex of problems: socio-political, economic, environmental [2]. At this time, the situation is complicated by an armed conflict with external intervention. Suppose that if there is political will, an armed conflict can be resolved in a short time. Unfortunately, however, environmental issues are not solved with paper-based solutions. Considering Donbass as a mining region focused on an exclusively industrial character of industrial development means its rapid decline. It is necessary to focus on the sustainable development of territories, human potential, preservation and restoration of the ecological state of the environment as the main factors of development and the resource base of the region. Industrial development should ensure the ecological balance of the territory. Now the agglomerations of Luhansk and Donetsk regions form a continuous network of settlements and industrial zones, cut natural landscapes, destroy and displace them [3, 4]. 
A decrease in industrial potential, the decline of mono-industrial cities are recorded. The violated territories are increasing. A paradox is created when there are large areas of abandoned territories, and a shortage of reserve territories for the development of populated areas. The task is to preserve the urban green landscapes of urbanized agglomerations, the reproduction and development of adapted green spaces. The forestry of the region is predominantly artificial, but there is accumulated experience, the goals and objectives of functioning have been determined. In cities, fullfledged scientific observations are episodic. In many cases, local authorities provide planting of flower beds and sanitary pruning of trees.

The goal of research is to determine the species composition of green spaces characteristic of the cities of the Luhansk region and to establish a group of plants that are maximally adapted to independent growth in the urban landscape.

\section{To achieve the goal, it is necessary to solve the following tasks:}

Analyze the quantitative and species composition of public green spaces in the city;

Calculate the compliance of green areas with the state buildings code requirements on the general plan of the city of Alchevsk;

Determine the species of trees and shrubs that normally grow and reproduce on the territory of the city without additional guardianship;

Develop general recommendations for improving the quantitative and species composition of green spaces in the city to improve the ecological state of the urban area.

The methodology provides for the analysis of the compliance of the number of green spaces in urban areas of general use with the requirements of state building codes. Based on long-term observations of city areas that are not subject to sanitary cleaning or the cultural influence of urban utilities, the species of trees and shrubs that grow and reproduce independently are determined. The article analyzes the existing and design solutions of the general plan of the city of Alchevsk in the current state and perspective urban planning forecast. Typical elements of the urban planning structure were selected for the study. This is one of the city's microdistricts, areas of green spaces within sanitary protection zones, separate 
public gardens and public parks, green spaces of schools and kindergartens, green spaces of streets. Thus, a high representativeness of the observation sample was achieved in terms of time span and in terms of the quantitative and species composition of green spaces.

\section{Main Body.}

Ukrainian Donbass today - an industrial tired region, overloaded with the problems of unbalanced growth, has gone into decline. Historically, within a short period of time, the former Wild Field turned into an urbanized industrial region [1].

It can be considered that the development of the region took place in a colonial way, when the territorial resource was used to the maximum, without reservations for future development / state.

The history of the development of Donbass, factors, circumstances, prerequisites for its existence have been studied by many scientists $[1,5,6,7]$. The territory of the region is 53.2 thousand sq. km., the population of the Luhansk and Donetsk regions is $6,260,000$ people together, which is comparable to the size of individual European states. Among 47 European countries, 27 have a population of less than $6 \mathrm{mln}$. person [4].

The level of urbanization in Luhansk and Donetsk regions is the largest in Ukraine. As of 2014, the percentage of the urban population of the regions reached $80-90 \%$.

Accordingly, in the modern period, Donbass is faced with a complex of severe environmental problems, which include general pollution of the territory, pollution of water resources, degradation of small rivers and reservoirs, a large volume of territories occupied by heaps, dumps, landfills for storing industrial waste, solid waste. In the cities of Donbass, the curtailment of the industrial base is recorded, caused by objective factors. The industrial zones of the cities were formed according to the redundant principle. Similar enterprises in developed countries occupy territories that are several times smaller [6]. Since most of the enterprises during the Soviet era were focused on the production of military products, or had a narrow specialization in the national economic balance, now such enterprises have been stopped. Plots of cities are turning into wastelands. A paradoxical situation is created - there is not enough territorial 
resource for sustainable development, but there are large territories that are unusable or abandoned.

An example is the general plan of Alchevsk, which provides for development at the expense of a residential zone, partly a green zone, despite the fact that there are large areas of the so-called inconvenient industrial areas. Unfortunately, capital has the ability to influence decision-making, and chooses not an environmentally friendly option, but a profitable option, when the city's territory is used, green zones that are most convenient for quick development. [8]

The territory of the Luhansk and Donetsk regions is predominantly steppe, $70 \%$ of the forests here were planted artificially. The main function of plantations in the Donbass is to protect the land from dust storms and erosion. Some of the Soviet plantations still need to be updated, another part, mainly oak and pine plantations, is drying up. There are no industrial forests in the region, which means that the Donbass forest needs full state funding. Local administrative forestry enterprises are able to sell wood mainly from sanitary felling, which is cheap firewood. According to the estimates of the State Forestry Agency in Donbass, over the past three years there have been 1,068 fires on an area of more than 16,000 hectares, which is about $15 \%$ of all forest plantations in the region.

Most of them cannot be restored yet due to mined areas. Losses from forest fires amount to almost 50 million hryvnias. The forest fires of summer 2020 were especially dangerous. However, the greatest harm from fires is not material, but environmental, because the forests of Donbass, first of all, should perform an environmental function.

In 2020, tens of thousands of hectares of forests burned down as a result of anomalous causes, which were probably artificially used in the context of an armed conflict. It also damaged the nature and ecology of the region.

The Donbass region has always belonged to the zone of risky agricultural use.

The steppe zone, poor in water resources in the conditions of archaic agriculture, could not provide a large number of the population. The borderland at the intersection of trade routes and zones of influence of several state formations - the Ukrainian 
hetmanate, the Crimean Khanate, Moscovia, the Caucasus caused the absence of a centralized power with cities, consolidated the status of the territory.

Human civilizational activity has changed the natural climatic landscape of Donbass. For a century and a half, instead of a sparsely populated rocky steppe, an urbanized industrial region was formed. Natural flora and fauna partially adapted, partially transformed (Fig. 1).

The task is to assess the prevailing conditions and determine the most adapted types of green spaces that are able to reproduce local natural landscapes.

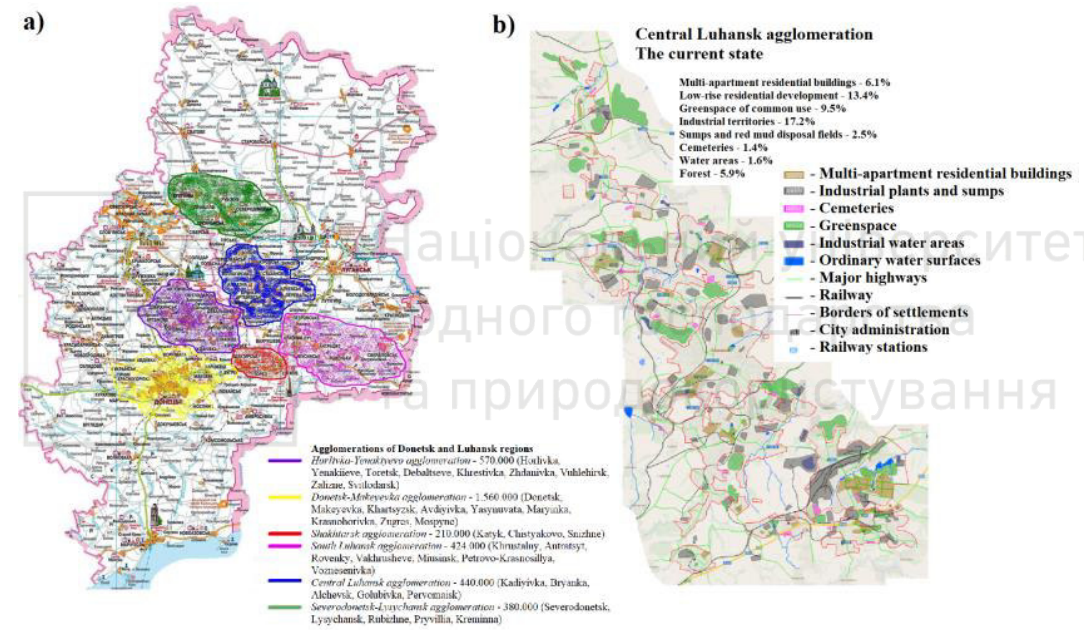

Fig. 1. $a$ - the agglomerations of Donetsk and Luhansk regions; $b$ - the scheme of the division of the Central Luhansk agglomeration

Changes in the natural landscape due to the nature of the industry prevailing in the Donbas. The mining and metallurgical complex was characterized by large volumes of consumption of mineral resources, huge volumes of industrial waste. The basic mode of transport for industrial needs is the railroad. The landscape has acquired the characteristic features of human activity. The visiting card of the region is waste heaps. Now their number reaches 1200. Large areas are occupied by rock and slag dumps, sludge collectors, landfills, dumps. It can be argued that the territories suitable for urban planning activities are generally used. There are no significant 
reserve territories left. That is, the stage of extensive development should be changed to rational, economical and careful use of the existing territories of urban and rural settlements with the aim of their sustainable development $[7,9,10]$. There are two options, the first is artificial. With the availability of modern technologies, it is possible, conditionally, to grow any types of plants. For example, exotic palms. But this comes at a fixed cost. The second option is to determine the types of plants, green spaces that feel comfortable in the prevailing conditions and are able to provide a green balance of the territory at minimal cost.

Analysis of experimental data. At present, no work has been carried out in the city of Alchevsk to determine the species composition of existing greenery, their distribution by age and suitability for further use.

This paper presents the results of research to determine the species composition of existing greenery, their distribution by age and suitability for further use. Surveys of green areas were conducted in the city of Alchevsk in the period from 2010 to 2014. The period of existence and formation of the studied green areas began in 1990.

Alchevsk is a city of regional subordination, located in the west of Luhansk region, $46 \mathrm{~km}$ from Luhansk on the line Rodakove Debaltseve and the highway M 04 Znamyanka-Donetsk-Izvaryne.

The territory of the city within the existing city boundary is 4901.0 ha, according to the reference plan - 5170 ha [11].

The economic complex of the city is multi-branch. The structure of the economy is formed by the following industries: industry, construction, external transport, services. As of 01.01.2008, about 52.3 thousand people were employed in all types of economic activity on the territory of the city, according to the regional statistics department [11].

Alchevsk is a significant cultural center that serves not only the population of the city itself, but also nearby settlements. The city has a number of research and design institutes, universities and special educational institutions, cinemas, palaces and houses of culture, cultural and leisure centers. The city has a stadium, sports facilities and complexes.

The city borders on the south - with the city of Perevalsk, on the north, east and west - with the lands of Perevalsk district. 
Alchevsk is part of the Alchevsk-Stakhanov settlement system, which is formed in one of the most urbanized regions of Donbass the south-western part of Luhansk region.

The population of Alchevsk is one of the medium-sized cities of Ukraine.

The current population of the city at the beginning of $2014-110$ thousand people.

The housing stock of the city of Alchevsk is 2689.1 thousand $\mathrm{m} 2$ of the total area, including multi-apartment - $80.7 \%$, manor-type $19.3 \%$.

The average housing supply in the city of Alchevsk is $23.2 \mathrm{~m}^{2}$ per capita.

The main industries of the city are metallurgy and coke industry. The main enterprises of the city are PJSC "Alchevsk Metallurgical Plant" and PJSC "Alchevskkoks".

The area of existing parks and public gardens in the city is 84.0 hectares. Taking into account the approximate level of landscaping of $80 \%$ of the existing plantations, the area of landscaped public areas is 67.0 hectares.

Provision of the city population with green areas of common use $5.7 \mathrm{~m}^{2} /$ inhabitant.

The territory of Alchevsk is located in the northern part of the steppe Donetsk physical-geographical region, on the northern slope of the Donetsk ridge, in the basin of the White and Lozova rivers (both are right tributaries of the Luhanka River), on their watershed divided by a ravine system. Most of the city is located in the Lozova River basin.

Orographic conditions of the territory are as follows. The surface of the territory is characterized by a very rugged relief (the depth of intersection reaches $180 \mathrm{~m}$ ) and a developed ravine network, which led to its significant erosion. In the submeridional direction, the city is crossed by a large branched Dovzhik gully with a watercourse regulated by a cascade of ponds - Yashchykivska, Likarnyany, Shkilny, Vasylivsky, Pershiy and Druhy Orlov. Temporary and permanent flows are observed in the thalwegs of other gullies. Absolute marks of the territory within the city are $122-290 \mathrm{~m}$, with a decrease to the bottom of the gullies and the minimum values in the water cut of the ponds. 
Within the city there are significant areas occupied by eroded steep slopes (with surface slopes of $15 \%$ or more) of a natural nature. As a result of intensive economic activity, the natural landscape has undergone radical changes and the manifestation of man-made landforms in the city (dumps, accumulating spoil tip, etc.).

Hydrological features. The territory of the city of Alchevsk is located on the watershed between the rivers Lozova and Bila, which are right tributaries of the river Lugan. An unnamed stream flows through the town from southwest to east in the Dovzhik gully, which flows into the Bila River near the village of Mykhailivka. In the north of the city there is a Kalinov gully, which flows into the river Lozova.

The main source of water for watercourses and reservoirs is atmospheric and groundwater. Therefore, their hydrological regime is characterized by spring level rise during floods and prolonged lowwater lows with individual torrential floods. The peak of spring floods is observed in the second and third decades of March. The limit is set in April and lasts 6-7 months (the lowest levels are observed in summer - in July - September, in winter - in December January).

The surface waters of the city are supplemented by a network of ponds: Yashchykivska, Likarnyany, Shkilny, Vasylivsky, Pershiy and Druhy Orlov. Reservoirs of the First and Second Eagle Ponds are promising for recreational use, but have unsatisfactory sanitary condition, partially silted and swampy shores and need rehabilitation.

The only place for recreation of locals is Isakovskoe reservoir. It was created by blocking the White Dam in order to provide technical water supply for industrial enterprises of the city.

The reservoir stretches from north to south along a length of 6.95 $\mathrm{km}$. The length of its shoreline is $15.2 \mathrm{~km}$ (excluding the shore of the mouth of the White River). The average depth of the reservoir is 5.75 $\mathrm{m}$, the maximum is $16.7 \mathrm{~m}$. With a normal supporting horizon $(110.04 \mathrm{~m})$, the area of the reservoir is $2.64 \mathrm{~km}^{2}$, the capacity is 20 million $\mathrm{m}^{3}$ of water. It is fed by meltwater, stormwater and river runoff. Precipitation does not have a significant effect on nutritional conditions, as very large losses on evaporation and filtration. The level of filling of the reservoir depends on the water content of the year, in this regard, the provision of depths is different. The bowl is 
located in Carboniferous deposits and is hydrogeologically characterized by a low level of underground supply.

Climatic conditions of the district are characterized by greater continentality (compared to other steppe regions of Ukraine) and aridity.

A brief description of climatic conditions is given by the average annual data of long-term observations of the main meteorological indicators at the meteorological stations Debaltseve and Popasna.

The air temperature is $6.7{ }^{\circ} \mathrm{C}$. The absolute maximum temperature is $39^{\circ} \mathrm{C}$. The absolute minimum temperature is minus $38^{\circ} \mathrm{C}$. The duration of the frost-free period is 166 days.

Estimated temperatures: the coldest 5 -day - minus $26^{\circ} \mathrm{C}$ - winter ventilation - minus $11.7^{\circ} \mathrm{C}$.

The heating period is 189 days.

Its average temperature is minus $2.3^{\circ} \mathrm{C}$. Depth of soil freezing avg./max. $-60 \mathrm{~cm} / 105 \mathrm{~cm}$. Relative humidity $-75 \%$. Precipitation (including during the warm period) $-525 \mathrm{~mm}(338 \mathrm{~mm})$. The maximum height of snow cover is $30-35 \mathrm{~cm}$. Dominant winds, their frequency:

eastern -

northeastern -

$17.3 \%$

south-eastern -

$15.8 \%$;

$14.6 \%$.

The wind speed is $5.1 \mathrm{~m} / \mathrm{s}$. The largest winds are possible: annually - $25 \mathrm{~m} / \mathrm{s} ; 1$ time in $5-10$ years $-29-31 \mathrm{~m} / \mathrm{s} ; 1$ time in $15-20$ years $-32 \mathrm{~m} / \mathrm{s}$. Special atmospheric phenomena (average / maximum number of days) from:
fog -
$106 / 143$
blizzard -
$22 / 42$
thunderstorm -
$29 / 40$.

It should be noted that the wind regime in the city is relatively favorable in terms of conditions for the transfer of emissions from sources of pollution - the main sources are located west of housing in the city, in the same direction and dominated by the transfer of pollution of the main industrial zone.

The area has a high natural potential for air pollution and is characterized by unfavorable meteorological conditions for dissipation of emissions into the atmosphere. 
In accordance with the zoning of climatic and construction purposes the territory belongs to III B of the climatic zone of the eastern steppe [1].

The complex geological structure and intersection of the relief, different conditions of humidification of the region have led to the heterogeneity of the soil cover of the city. The heterogeneity of soil formation conditions led to the formation of a large number of soil varieties, among which about $90 \%$ belong to chernozem.

According to the agro-climatic zoning of Ukraine, the territory of the city is located in the Donetsk steppe province, which is characterized by chernozems and sod gravelly soils formed on the eluvium of sandstones and shales. The soil cover is dominated by chernozems of medium and low humus, mainly on forest rocks, sod gravelly on the eluvium of non-carbonate rocks and chernozems gravelly on the eluvium of sandstones, sandy-clay and clay shales.

The mechanical composition of soils, which largely determines the level of their fertility, varies from light loam to light clay varieties, heavy loamy and sandy-medium loamy, gravelly soils predominate.

Soils on the slopes are eroded; soil erosion is $48-80 \%$.

Their level of natural fertility is high, but due to the intersection of the terrain the soils are very eroded. In addition, the specialization of the economy has led to extreme disturbance of soils (dumps, settling tanks, heaps, etc.).

Highly fertile meadow and meadow-chernozem soils were formed in the floodplain and in the bottoms of watercourses.

In accordance with the geological structure of mineral resources of the region are represented by building limestone, brick and tile raw materials, coal deposits. However, there are no mineral resources of industrial significance within the city.

According to the economic service of PJSC "AMK", the metallurgical complex of the city works mainly on imported raw materials: Kryvyi Rih iron ores, Nikopol manganese ores, Chasovyarsky sand, etc.

The results of experimental data processing. The main parameters of the territories occupied by green plantations of different types within the settlements are regulated by the state building code[12]. 
According to Table 5.1 [12], the area of green areas per inhabitant of the city should be $12 \mathrm{~m}^{2}$.

The share of green areas for various purposes within the city development (the level of landscaping) must be at least $45 \%$ for district III-B. In the city there are enterprises of the I class of harmfulness therefore according to appendix 1 to table 5.1 it is necessary to increase the resulted norms of city-wide green areas by 15-20 percent.

Thus, for the city of Alchevsk, the area of green areas per capita should be $12 \mathrm{~m}^{2} \times 1.15=13.8 \mathrm{~m}^{2}$.

The nomenclature of structural elements of the territory of the complex green zone of the city is determined according to appendix. [12]

City gardens, parks, squares, boulevards, forests within the city are public greenery.

Green areas of city streets and roads, streets of local significance, squares, transport interchanges and parking lots are green areas of special purpose.

Greenery in the city is divided into:

- urban forests green areas of common use area of 602.6 hectares;

- public green spaces - parks, forest parks, squares, boulevards;

- green areas in residential area and microdistrict without driveways, playgrounds and sports grounds are green areas of limited use;

- green spaces of limited use and special purpose on the territories of preschool and school educational institutions, higher educational institutions, medical institutions, sports and sports facilities, cultural institutions, trade enterprises, public catering and household services, nurseries, cemeteries;

- green spaces of limited use and special purpose in industrial, communal and warehouse territories in sanitary protection zones of enterprises of protective purpose.

The territory of public parks and squares located in the city of Alchevsk is 118.812 hectares.

There are 276 streets and alleys in the city of Alchevsk. It is not possible to survey green areas on all city streets. But, most likely, it is not necessary. 
Elements of the planning structure typical for the city were selected for the survey. This is one of the city's 400 microdistricts, which is typical in its territory, timing and type of development.

For the survey of the streets, typical building streets were selected, which cover the entire territory of the city.

These are streets that cross from east to west and from north to south of the city and form a continuous line.

From east to west Metallurg Avenue - Lipovenka Street Leningradskaya Street. Lenin Street is also Frunze Street.

From north to south of Hmyria and Gorky streets in the area from the transport tunnel to Zaporizhzhya, Kalinin and Kirov streets.

In the area of typical buildings of the 50-60s of the last century, three more intersecting streets were taken. These are Lenin Avenue, Belinsky Street and Moskovskaya Street.

Thus, by conducting a survey of 12 streets of the city, it is possible to get an idea of the quantitative and qualitative state of greenery of the street network of the city.

For the streets of the city of Alchevsk per $1 \mathrm{~km}$ of the street there are 0.9799 hectares of green areas for general and special purposes.

The area of the residential district 400 is 22.6754 hectares.

In addition, for the analysis of green areas of general use and special purpose were used materials of inventory of green areas, made to order KP "Alchevsk road maintenance site" in 2013 for the following objects:

- Square on the square of the 30th anniversary of the Victory;

- Belinskoho Street;

- Lenin street;

- Lenin Avenue;

- Lipovenka Street.

Materials of field surveys of green areas, conducted in 2011 in the neighborhood 400 .

Green areas of limited use and special purpose on the territories of preschool and school educational institutions, out-of-school institutions, higher and special educational institutions, medical institutions, cemeteries of Alchevsk were surveyed with the help of inventory documents for land use and topographic survey of 1: 2000 scale. Acts of inspection of green plantations on the territories of 
objects for which they were performed were also used. The total area of greenery is 63.8592 hectares.

The composition of green plantations of limited use and special purpose is determined.

A significant part of green areas in residential areas and public facilities, in recreational areas, along city streets, in enterprises and adjacent areas, as well as green areas for special use, are in satisfactory condition.

In total, 44 species of trees and 20 species of shrubs were registered in the surveyed area [13].

Trees near residential buildings, along the city streets have such a species composition (the order of change in the breed of the breed, the number of which is $2 \%$ ):

- Acer platanoides - 14.54\%;

- The horse chestnut (Aesculus hippocastanum) - 12.37\%;

- The black poplar (Populus nigra) - 9.31\%;

- European ash (Fraxinus exceisior) - 9.06\%;

- small-leaved lime (Tilia cordata) - 6.88\%;

- black locust (Robinia pseudoacacia) - 5.11\%;

- Armenian plum (Prunus armeniaca) - 4.85\%;

- Chinese elm (Ulmus parvifolia) - 4.8\%;

- Poplar Bolle (Populus bolleana Louche) - 3.2\%;

- Robinia (Robinia pceudoacacia f. umbraculifera) - 3.12\%;

- Ash-leaved maple (Acer negundo) - 2.88\%;

- Poplar canadian (Populus canadesis) - 2.27\%.

By breed composition, the largest groups, more than 5\%, are, maple (6 varieties) - 18.4\%, poplar (5 varieties) - 17.56\%, ash-tree (2 varieties) $-9.22 \%$, locusts ( 2 varieties) $-8.23 \%$, lime $-6.88 \%$ and elm ( 2 varieties) $-5.43 \%$.

In total, the above 12 species of trees $27.27 \%$ of the number of species occupy $78.39 \%$ of the total number of trees.

Shrubs near residential buildings and along city streets have the following breed composition (listed in descending order of the proportion of the breed, the number of which exceeds $2 \%$ ):

- Ligustrum vuigare - 89.61\%;

- Sirsnga vulgaris - $3.29 \%$.

The number of these shrubs changes from $1.88 \%$ to $0.01 \%$.

Two types of shrubs store $92.9 \%$ of the total number. 
The general condition of the trees is as follows:

- in the norm - 57.1\%;

- require sanitary pruning - $24 \%$;

- need rejuvenation - $11.5 \%$;

- trees need to be removed $-7.4 \%$

Most of the black poplar trees (more than $15 \%$ of the structural composition) are over 40 years old. Poplars are short-lived plants that are allergens (poplar down is a strong allergen). Also, these trees are largely damaged by the crown, skeletal branches and central conductor. Plants of this group should be gradually replaced by trees of another group.

Robinia and maple have damage to the crown and skeletal branches due to freezing, but much less than poplars. This requires sanitary pruning.

Other trees generally withstand the climatic conditions of the city of Alchevsk, do not have significant damage and need only appropriate sanitary pruning and rejuvenation.

To determine the species of trees and shrubs that reproduce in the city without human assistance, three sites were identified on which no economic activity was carried out. In 2016, a survey of green areas grown there was conducted at these sites. In the city of Alchevsk, elm, small-leaved, pinnate-branched and ash-shaped maple grow independently, which literally fill free areas (black elder), sharp-leaved maple (Canadian), robinia (white acacia), pyramidal poplar and black poplar, prickly dog rose [13].

To create new greenery and reconstruction of existing ones, it is desirable to expand the species composition of trees and shrubs. More to plant ailanthus, aronia, bitter cherry, gentian, walnut, mountain ash, pole, catalpa, silver sucker, Crimean pine, here, thuja, barberry, elderberry, hawthorn, viburnum, rose hips, dog rose shrubs. Additionally, introduce trees and shrubs that feel great in the city and are already used in forest plantations. These are buckthorn, buckthorn, pedunculate oak, Scots pine.

The number of green areas in the city does not meet the standards, it would be necessary to create additional ones. [8] The area of green areas for public use in the city is 118.8120 ha, 84 ha according to the Master Plan. According to the Master Plan, there is $5.7 \mathrm{~m}^{2}$ per one inhabitant of the city, according to the materials of the survey 10.75 
$\mathrm{m}^{2}$, according to the standards there should be $19.5 \mathrm{~m}^{2}$, or 220.3 ha of public green areas.

For the city of Alchevsk, the development of the Master Plans of the city has been carried out since 1946. The Kyiv Institute of Urban Design "Dipromisto" for the city Master plans were developed in 1968, 1993, 2011. [8] All these Master Plans pursued a single urban policy, including the placement of greenery.

The approved Master Plan of the city [8] provided for increasing the number of green areas for public use to $19.5 \mathrm{~m}^{2}$ per capita. Based on the prospective population, which was provided for in the master plan at the end of the calculation period, the area under public greenery was to be 347.4 hectares.

The master plan provided:

- creation of large-scale territories of green zones of 78.8 and 64.8 hectares in new areas of multi-storey buildings (Eastern 1 and Eastern 2);

- the central city park was planned to be created on the basis of Victory Park, with the expansion of its territory by 90 hectares;

- other green areas (parks, squares and boulevards).

The organization of the parks, which were outlined in the master plan, was not carried out.

To provide the residents of Alchevsk with the required number of green areas for public use, it is necessary to create additional green areas in the middle or near residential buildings so that in each residential area there is a park within walking distance. It is desirable to arrange the areas of squares within the neighborhoods in such a way that the green areas of schools, kindergartens and squares are united in one massif.

To organize new parks and gardens, use the existing green areas of the Sarmatian beam, located along the eastern border of districts 58 and 59.

Within the recreational zone, create a Forest Park around the Orlovykh Ponds, which will be at a distance of pedestrian accessibility from the multi-storey residential buildings of the district's 58, 59, 399, 400, 401 of the eastern part of the city.

In the northern part of the city to increase the territory of existing forests around the villages of Administrative and Briquetting. Additionally, plant 40 hectares of forest north of the slag dump of the 
metallurgical plant on Pivnichna Street in the free area between the forest tract and the Kalinov beam.

The zone of green plantations, both existing and projected, unites practically all functional zones of the city. It is formed from the existing green areas around the Hospital, School, Eagle ponds, areas that are planned to be transformed into meadows, parks, boulevards, green beams within the city. Landscaping of sanitary protection zones, organization of green passages along the streets, which together with large green spaces of parks, forests, meadows create a single system, a kind of ecological framework of the city.

The main green areas are planned to be located along the Eagle Ponds and in the northern part of the city.

Taking into account the approximate level of landscaping of existing parks and squares by $80 \%$, the area of green public areas is 95.0 hectares.

There is $8.6 \mathrm{~m}^{2}$ of green areas per capita, which is much lower than the norm [12].

The calculation of the required area of public green areas is performed for the population of the city in the future in accordance with the state building code [12]. The calculation is performed for the prospective population of the city within the existing and prospective limits for the calculation and urban planning forecast.

Given the existing green areas of public use -95.0 hectares, it is necessary to organize new green areas of public use:

- for the settlement period - 162 hectares;

- on the town-planning forecast - 166 hectares.

Thus, according to the decisions of the master plan, the territory of parks, squares, boulevards of public use in the city will be about 368 hectares, including green areas of public use - 278 hectares.

Per 1 inhabitant, in the future, green areas of common use will be $22.2 \mathrm{~m}^{2}$ (against 20.8 hectares according to the standard).

\section{Conclusions.}

Based on the results of this work, it is possible to draw the following conclusions.

The actual area of green areas for public use in parks, gardens, boulevards, forests within the city, which is 602.6 hectares of forests and 95.0 hectares of parks, gardens, boulevards. 
The actual area of green plantations of limited use and special purpose in the territories of preschool and school educational institutions, higher educational institutions, medical institutions, cemeteries are determined.

On the territory of schools' green plantations occupy 10.0680 hectares $-31.1 \%$ of the territory. The average area of land per school is 1.9038 hectares, green areas 0.5922 hectares.

On the territory of out-of-school institutions green plantations occupy 3.3047 ha $-35.4 \%$ of the territory. The average area of land per out-of-school institution is 1.0376 ha, green areas 0.3672 ha.

On the territory of preschool educational institutions green plantations occupy 5.9639 hectares $-32.0 \%$ of the territory. The average area of land per preschool is 0.7159 hectares, green areas 0.2294 hectares.

On the territory of higher educational institutions green plantations occupy 7.6991 ha $-34.0 \%$ of the territory.

On the territory of medical institutions green plantations occupy 18.6160 ha $-59.1 \%$ of the territory.

On the territory of cemeteries 101.1695 green plantations occupy 18.2075 ha $-18.0 \%$ of the territory.

We consider it possible to use certain areas of greenery for a school, preschool educational institution, out-of-school educational institution when calculating the balance of the territory for cities with a population of 100-150 thousand inhabitants $[13,14]$.

For the city streets, the average area of greenery per $1 \mathrm{~km}$ of street length is determined, which is 0.9799 ha of green spaces for general and special purposes. The actual non-compliance of the total areas of green plantations with the standards established by the DBN can be considered a constant trend. Normative values of the number of areas of green plantations in accordance with DBN $-13.8 \mathrm{~m}^{2}$ and the General Plan of the city $-19.5 \mathrm{~m}^{2}$ per capita were not achieved.

In the city there are enterprises of the I class of harmfulness therefore it is necessary to increase the resulted norms of city-wide green territories by 15-20 percent. Given the existing green areas of public use - 95.0 hectares, it is necessary to organize new green areas of public use: - for the calculation period - 162 hectares (increase by $70 \%$ ); - urban forecast - 166 hectares (increase by 75\%) $[8,13]$. 
The actual species composition of trees and shrubs growing on the city streets and on the territory of the typical city district has been determined. There are 44 species of trees and 20 species of shrubs registered in the city. The species composition of trees and shrubs used for landscaping is desirable to expand due to species that feel good in the city.

The results of the study can be taken into account in the development of measures for landscaping of urban areas and restoration of ecologically disturbed urban areas of industrial cities of Luhansk region.

\section{References}

1. V. B. Molchanov, Ukrai'ns'kyj Donbas - ekonomichne dyvo drugoi' polovyny XIX - pochatku XX st., Grani istorii': zb. nauk. prac'. Special'nyj vypusk materialy II Vseukrai'ns'koi' naukovo-praktychnoi' konferencii' «Bahmuts'ka starovyna: krajeznavchi doslidzhennja - 2018», 1(9), 103-113 (HIFL, Bahmut, 2018)

2. V. Zh. Popov, Pasynky proletars'koi' revoljucii': robochi mista Ukrai'ny v umovah gumanitarnoi' katastrofy 1917-1920 rr., Grani istorii': zb. nauk. prac'. Special'nyj vypusk - materialy II Vseukrai'ns'koi' naukovo-praktychnoi' konferencii' «Bahmuts'ka starovyna: krajeznavchi doslidzhennja - 2018» 1(9), 121-126 (HIFL, Bahmut, 2018)

3. N.M. Demyn, Gorodskye aglomeracyy v kontekste yssledovanyja fenomena form y system rasselenyja, Mistobuduvannja ta terytorial'ne planuvannja: Nauk. tehn. zbirnyk, 45(1), 3-15 (KNUCA, Kyiv, 2005)

4. Mis'ki aglomeracii' Ukrai'ny, https://uk.wikipedia.org/wiki/ Міські агломерації України Accessed 25 October 2020

5. S. Kul'chyc'kyj, L. Jakubova, Donechchyna i Luganshhyna u XVII-XXI st..: istorychni faktory j politychni tehnologii' formuvannja osoblyvogo ta zagal'nogo u regional'nomu prostori (NASU Institute of History of Ukraine, Kyiv, 2015)

6. A.P. Ositnjanko, Planuvannja rozvytku mista (KNUCA, Kyiv, 2001)

7. V. A. Jacenko, Teoreticheskie i prakticheskie idei novogo gradostroitel'stva Donbassa: ikh proshloe, nastoyashchee $\mathrm{i}$ budushchee, Mistobuduvannja ta terytorial'ne planuvannja: nauk.-tehn. zb., 21, 359-366 (KNUCA, Kyiv, 2005)

8. Alchevs'k Lugans'koi' oblasti. General'nyj plan. Derzhavne pidpryjemstvo Ukrai'ns'kyj derzhavnyj naukovo-doslidnyj instytut proektuvannja mist «Dypromisto». $2010 \mathrm{r}$.

9. Ye.Ye. Klyushnychenko, Rekonstruktsiya zhytlovoyi zabudovy (KNUCA, Kyiv, 2000)

10. The Law of Ukraine "On the Complex Reconstruction of Quarters (Microdistricts) of an Outdated Housing Fund" 
11. Lugans'ka oblast' u cyfrah. Statystychnyj zbirnyk. Derzhavnyj komitet statystyky Ukrai'ny. Golovne upravlinnja statystyky u Lugans'kij oblasti. Lugans'k 2006-2012 rr.

12. DBN B.2.2-12:2019, Planning and building of territories (Ministry for Communities and Territories Development of Ukraine, Kyiv, 2019)

13.V.M. Sokolenko, O.E. Podljevs'kyj, analiz kolichestvennogo i kachestvennogo sostojanija zelenyh nasazhdenij na territorii zhiloj zastrojki goroda Alchevska Luganskoj oblasti, Zbirnyk naukovyh prac' Donbas'kogo derzhav nogo tehnichnogo universytetu, 1(46), 94-101 (DonSTU, Lysychans'k, 2017)

14. Yu.N. Belokon' Regional'noye planirovaniye - teoriya i praktika. (Logos, Kyiv, 2003)

https://doi.org/10.31713/m1030

\section{HYPOCHLORITE GOLD LEACHING AN ALTERNATIVE TO CYANIDE TECHNOLOGY}

Prokopenko V.A.
F.D. Ovcharenko Institute of Biocolloidal Chemistry NAS
of Ukraine, Kyiv, Ukraine; doctor of technical sci., director
Chernenko V.Yu.
National Technical University "Igor Sikorsky Kyiv Polytechnic
Institute", Kyiv, Ukraine; cand. med. sci., professor assistant
of Chemical Technology Faculty
Vorotytsky P.V.
Tsyganovich O.A.
of Ukraine, Kyiv, Ukraine; graduate student
F.D. Ovcharenko Institute of Biocolloidal Chemistry NAS
of Ukraine, Kyiv, Ukraine; PhD, deputy director on scientific work
Volobaiev I.I.
F.D. Ovcharenko Institute of Biocolloidal Chemistry NAS of
Ukraine, Kyiv, Ukraine; PhD, researcher
Abstract
Traditional technologies of gold mining are exhausted due to the depletion of
stocks of conditioned raw materials at functioning gold mining enterprises, in
addition, the preservation or disposal of large-scale waste of these technologies
requires significant financial costs for environmental protection measures.

